\title{
Comparing Tactical Behaviours of Youth Soccer Teams Through the Test "GK3-3GK"
}

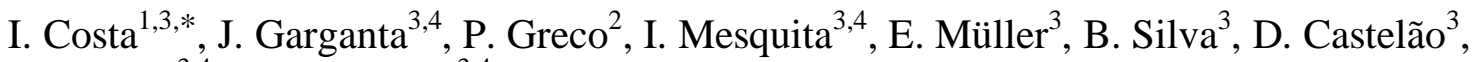 \\ A. Rebelo ${ }^{3,4}$ and A. Seabra ${ }^{3,4}$ \\ ${ }^{I}$ University Center of Belo Horizonte, UNI-BH, Belo Horizonte, MG, Brazil \\ ${ }^{2}$ Federal University of Minas Gerais, UFMG, Belo Horizonte, MG, Brazil \\ ${ }^{3}$ Faculty of Sport, University of Porto, FADEUP, Porto, Portugal \\ ${ }^{4}$ Centre of Research, Education, Innovation and Intervention in Sport, CIFI'D, FADEUP, Porto, Portugal
}

\begin{abstract}
This study aimed to compare the tactical behaviours performed by youth soccer players from four different age groups, using the "GK3-3GK test". For such a purpose, 52 players (16 Under-11s, 12 Under-13s, 12 Under-15s and 12 Under-19s) from four Portuguese teams have been analyzed. These players performed 2853 tactical actions. It was carried out descriptive analysis, Kolmogorov-Smirnov, Chi-square and Kappa de Cohen. The results point up significant statistical differences between the youth teams for tactical actions performed according to game principles and place of action $(\mathrm{p} \leq 0.05)$.

Statistical differences were found on the "Defensive Unity" between Under-11 and Under-13 players ( $\mathrm{p}=0.03$ ). Another differences can be seen regarding the principles of "Penetration", "Defensive Coverage" and "Balance", between Under15 and Under-19 $(\mathrm{p}=0.00)$. It is also possible to assert that Under-19 players show of the highest time of ball possession and Under-13 players were placed many times behind the line of the ball while they are attacking. In conclusion, it is stated that tactical behaviours performed by soccer players are different, concerning players' age. Thus, it is recommendable that the coach should have great knowledge and evaluation about abilities and difficulties of each player to improve them with the training process.
\end{abstract}

Keywords: Tactical behaviours, game principles, soccer.

\section{INTRODUCTION}

In last years, the tactical and the cognitive processes have been considered essential for the performance of Soccer players and teams [1,2]. Because of that, researchers are studying more about theses subjects. The increase of the researches is facilitating to understand and characterize the actions of the game concerning individual and collective organizational [3].

Researchers have used the Notational Analysis [4] and Observational Methodology [5] procedures to analyze the games and get information about the performance of the players and teams. These tools provide information relevant about the behaviors of players and verify the evolutions and the tendency of the game.

The procedural and declarative tactical knowledge have been another important subject that has been studied by the researchers. Scientific evidences have shown that the procedural tactical knowledge can be different between

*Address correspondence to this author at the Centro de Estudos em Cognição e Ação (CECA), Escola de Educação Física, Fisioterapia e Terapia Ocupacional da UFMG, Av. Presidente Antônio Carlos, 6627Pampulha, Belo Horizonte - Minas Gerais - Brazil; Cep: 31.310-250; Tel/Fax: 0XX (31) 3499-2325; E-mail: israelteoldocosta@googlemail.com youth soccer players [6]. Thus, this study aims to compare the tactical behaviours performed by youth soccer players from four different age groups using the "GK3-3GK test.

\section{MATERIAL AND METHODS}

\section{Participants and Sample}

In the present study, 52 players ( 16 Under-11s, 12 Under$13 \mathrm{~s}, 12$ Under-15s and 12 Under-19s) from four Portuguese teams have been analyzed. These players performed 2853 tactical actions. Data from throw-ins, free kicks and situations where the player didn't move, were not analyzed.

\section{Applied Method}

Players performed a 4 minute small-sided game ( 3 vs. 3 with goalkeepers). The "GK3-3GK" test is designed in a field of 36 meters length and 27 meters width. With the exception of the offside rule, all official soccer rules were applied. The test aimed to evaluate the tactic actions performed by players (with and without the ball) attending on ten fundamental tactical games principles. Additionally, the test considered the place of action and action outcome.

\section{Procedure}

The data for our study was attained in four different clubs with directors' permission. Prior to the test, a brief explana- 
tion of the objectives was given to the players. The teams were formed randomly and the players were wearing numbered vests in order to facilitate their identification. A thirtysecond period had been granted to familiarize them with the test and after which the game began.

\section{Materials}

The games had been recorded with the digital camera PANASONIC NV - DS35EG. The digital videos were transferred to a laptop via cable and converted into "avi" files.

Table 1. Game Principles, Place of Action and Action Outcome from the "GK3-3GK" Test.

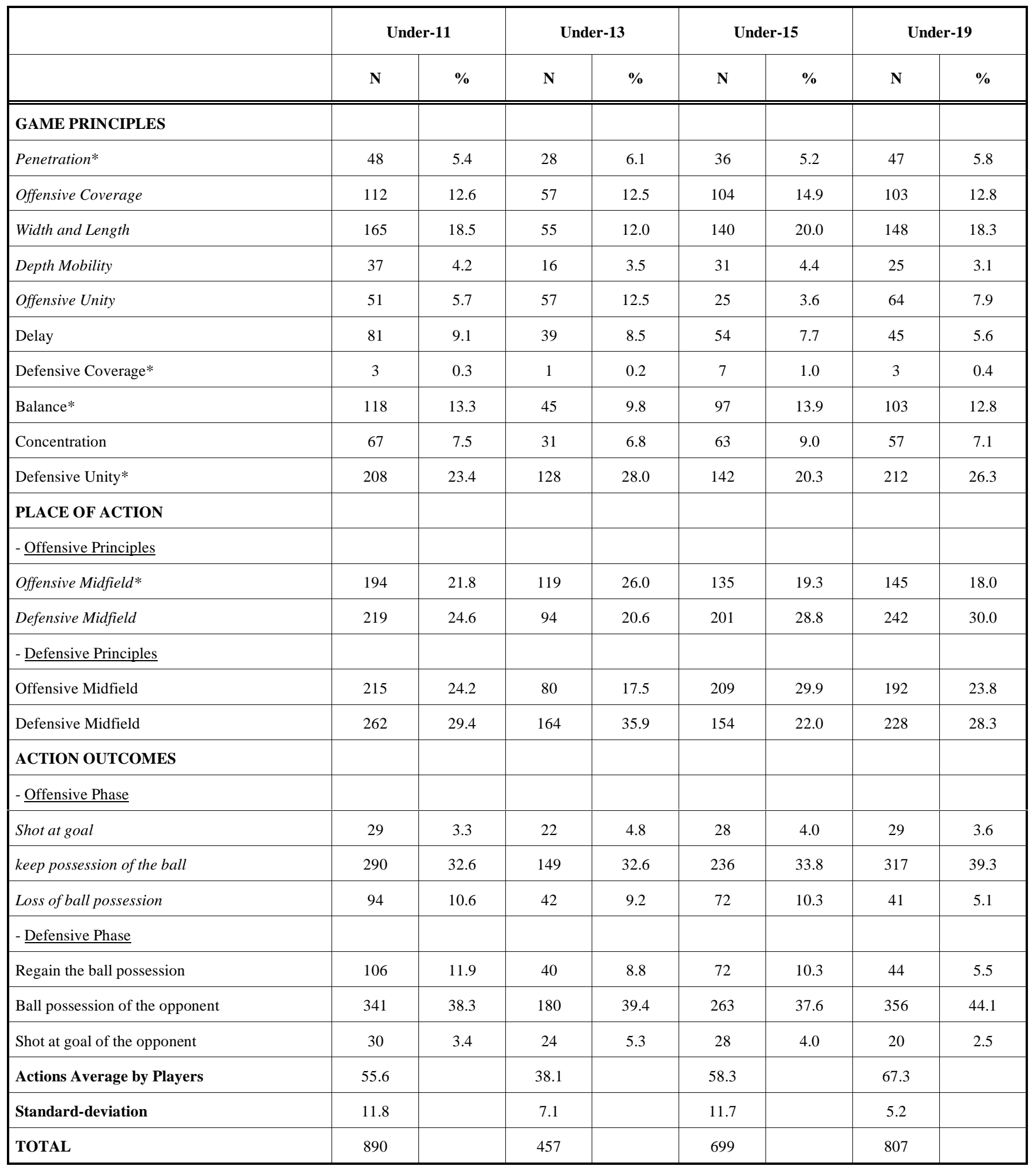

(*)Significant statistics differences $(\mathrm{p}<0.05)$ between Under-11 and Under-13 ( $\mathrm{p}=0.03$ ) for the Principle of "Defensive Unity" and between Under-15 and Under-19 ( $\mathrm{p}=0.00)$ for the principles of "Penetration", "Defensive Coverage" and "Balance". Offensive Principles perform on the Offensive Midfield between Under-13 and Under-11, Under-15, Under-19. 
Softwares Utilius VS and Soccer Analyser were used for data processing.

\section{Statistical Analysis}

Statistical procedures were done using SPSS for Windows $^{\circledR}$, version 17.0. Descriptive analyses (frequency and percentage) for the variables (principles, place and outcomes) were done to characterize the sample. The normal distribution of the data was verified by the test of Kolmogorov-Smirnov and homogeneity of variances was assured by test of Levene. The Chi-square Test $\left(\mathrm{K}^{2}\right)$ with a significance level of $p<0.05$ was used to verify the association between the frequency of the principles performed by four different age groups. The Kappa of Cohen coefficient was used to check inter- and intraobservers reliability.

\section{Reliability Analysis}

To determine the reliability of the observation, the testretest method was used to obtain the stability-reliability coefficient. Three observers were trained to review 1008 tactical actions that represent $35.3 \%$ of the sample. This percent is above of the value of reference (10\%), recommended by the literature [7]. The results reveals an inter-observers agreement coefficient of 0.92 (standard deviation $=0.02$ ), 0.87 (standard deviation $=0.02$ ) and 0.90 (standard deviation $=0.02$ ) and intra-observers agreement coefficient of 0.90 $($ standard deviation $=0.02), 0.88($ standard deviation $=0.02)$ and 0.91 (standard deviation $=0.01$ ). These values are above the conventional level of acceptance (0.61) [8].

\section{RESULTS AND DISCUSSION}

Table 1 shows the tactical actions frequencies related with game principles, place of action and action outcome.

It is possible to state that the mean of tactical actions performed by players Under-19s is higher when compared with the other youth teams. Probably, it happens because Under19 age group have highest ball possession in the defensive midfield, where the risk to lose the ball is slighter.

Table 1 also presents the highest frequencies for the offensive actions of "Width and Length" for Under-19, Under15 , and Under-11 age groups. For Under-13 the same trend was observed in the offensive actions of "Offensive Unity". Apparently, it occurs because the Under-13 players were placed often behind the line of the ball and out of the "Center of the Game" when the team was attacking.

Regarding the defensive principles, the highest frequency of actions is related to the principles of "Defensive Unity" for all groups. For Under-15 age group the frequency concerning the principle of "Balance" is lower than the other youth teams. Probably, it shows that the players of Under-13, when marking opponents, stay away from the "Center of the Game".

Statistical differences were found on the "Defensive Unity" between Under-11 and Under-13 players ( $p=0.03$ ). Another differences can be seen regarding the principles of "Penetration", "Defensive Coverage" and "Balance", between Under-15 and Under-19 ( $\mathrm{p}=0.00)$.

Under-13 team differs from the other teams about the place of action when players perform the offensive principles $(\mathrm{p}=0.00)$. It was found an expressive value to the offensive midfield actions (26.0). This shows that Under-13 players perform more actions on the offensive midfield than the other youth teams.

Also, it was confirmed that the players of Under-13 team perform a greater number of actions related to the defensive principles on the offensive midfield. Probably, it shows a particular type of defensive team organization. They pressure in areas more advanced than others youth teams.

The frequency of the action outcomes in the offensive phase seems to be similar for all the teams, except Under- 19 . The percentage for the variable "Keep possession of the ball" was superior to others youth teams $(16.1 \% \pm 1.7)$. For the variable "Loss of ball possession" the percentage was lower, with value of $96.4 \% \pm 14.3$. The Under-19 players give the impression that they prefer to keep the ball until they find the best solution.

Regarding the defensive phase, differences in the frequency between the Under-19 and the others youth teams were found. These differences are related to "Regain the ball possession" and "Shot at goal of the opponent $(87.7 \% \pm 28.7$ and $68.4 \% \pm 38.3$, respectively). Statistical differences were not found for the outcomes of tactical actions performed by the players.

Therefore, it is possible to conclude that there are statistical differences between the youth teams for tactical actions performed according to soccer game principles and the place of action. Also there are differences in the percentage outcomes, but they are not statistically significant. It is also possible to assert that Under-19 players kept the possession of the ball until they find a better solution and Under-13 players were placed many times behind the line of the ball while they are attacking.

Base on these results it is also plausible to conclude that tactical behaviours performed by soccer players are different concerning ages of players. So, the coach should have great knowledge and evaluation about abilities and difficulties of each player to improve them with the training process.

\section{REFERENCES}

[1] Greco P. Conhecimento técnico-tático: o modelo pendular do comportamento e da ação tática nos esportes coletivos. Revista Brasileira de Psicologia do Esporte 2006:107-29.

[2] Garganta J. Modelação táctica do jogo de futebol - estudo da organização da fase ofensiva em equipas de alto rendimento. Tese de Doutoramento. Porto: Universidade do Porto 1997.

[3] Gréhaigne JF, Bouthier D, Godbout P. Performance assessment in team sports (Evaluation de la performance en sports collectifs). J Teach Phys Educ 1997; 16(4): 500-16.

[4] Hughes C, Franks I. Notational analysis of sport. London: E. F.N Spon 1997.

[5] Anguera M, Blanco A, Losada J, Hernández A. La metodología observacional en el deporte: conceptos básicos. Lecturas: Educación Fisica y Deportes [digital paper]. 2000 Agosto 5(24). [Cited: 20 May 2009]; [around 36p.] Available in http://www.efdeportes.com 
[6] Giacomini DS. Conhecimento tático declarativo e processual no futebol: estudo comparativo entre jogadores de diferentes categorias e posições. Dissertação de Mestrado. Belo Horizonte: Universidade Federal de Minas Gerais 2007.
[7] Tabachnick B, Fidell L. Using multivariate statistics. New York: Harper \& Row Publishers 1989.

[8] Landis JR, Koch GC. The measurement of observer agreement for categorical data. Biometrics 1977; 33: 1089-91.

(C) Costa et al.; Licensee Bentham Open.

This is an open access article licensed under the terms of the Creative Commons Attribution Non-Commercial License (http://creativecommons.org/licenses/by-nc/3.0/) which permits unrestricted, non-commercial use, distribution and reproduction in any medium, provided the work is properly cited. 